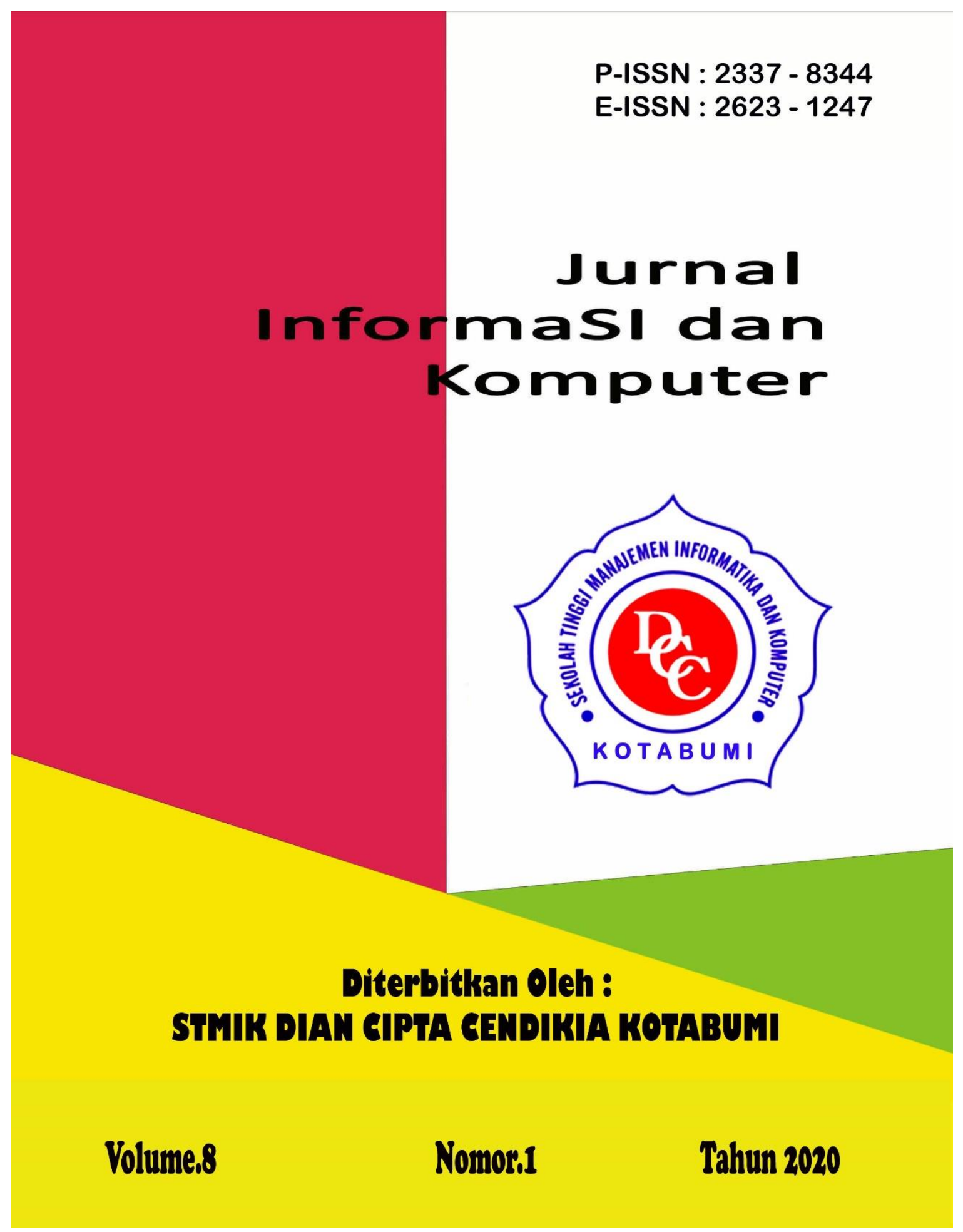


Penerbit:

STMIK DIAN CIPTA CENDIKIA KOTABUMI

Bekerjasama dengan LPPM STMIK DCC Kotabumi

Hak atas naskah/tulisan tetap berada pada penulis, isi diluar tanggung jawab

Penerbit dan Dewan Penyunting

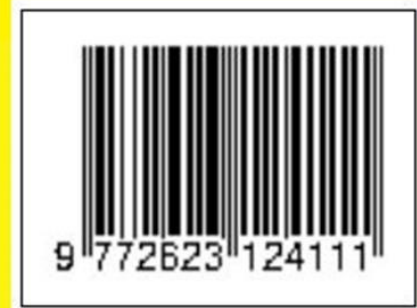




\section{PENGANTAR REDAKSI}

Puji syukur dipanjatkan kehadirat Tuhan Yang Maha Esa, atas karunia dan limpahan rahmatNYA jualah Jurnal Informatika dan komputer (InfoKom) STMIK Dian Cipta Cendikia Kotabumi ini dapat terwujud.Jurnal Informatika dan Komputer (InfoKom) yang terbit dua (2) kali dalam setahun ini merupakan suatu wadah untuk penyebar luasan hasil-hasil penelitian, studi pustaka, karya ilmiah yangberkaitan dengan Informatika dan Komputer khususnya bagi dosen-dosen STMIK Dian Cipta Cendikia Kotabumi serta umumnya para cendikiawan, praktisi, peneliti ilmu Informatika dan Komputer.

Harapan, dengan diterbitkannya Jurnal Informatika dan Komputer (InfoKom) ini sebagai salah satu bentuk sumbangan pemikiran dalam pengembangan ilmu informatika dan komputer yang berkaitan dengan kajian-kajian di bidang tekhnologi Informatik, Komunikasi Data dan Jaringan Komputer, perancangan dan Rekayasa Perangkat Lunak, serta ilmu-ilmu yang terkait dengan bidang Informatika dan Komputer lainnya.

Berkenaan dengan harapan tersebut, kepada para peneliti, dosen dan praktisi yang memiliki hasil-hasil penelitian, kajian pustaka, karya ilmiah dalam bidang tersebut diatas, dengan bangga redaksi Jurnal Informatika dan Komputer (JIK) menerima naskah ringkasan untuk dimuat pada jurnal Informatika dan Komputer (InfoKom) STMIK Dian Cipta Cendikia Kotabumi dengan berpedoman pada penulisan naskah jurnal sebagaimana dilampirkan pada halaman belakang (Bagian kulit dalam) buku jurnal ini.

Mutu dari suatu jurnal ilmiah tidak hanya ditentukan oleh para pengelolanya saja, tetapi para penulis dan pembaca jualah yang mempunyai peranan besar dalam meningkatkan mutu jurnal Informatika dan Komputer ini. Merujuk pada realita ini kamu sangat mengharapkan peran aktif dari peneliti untuk bersama-sama menjaga dan memelihara keberlangsungan dari jurnal Informatika dan Komputer STMIK Dian Cipta Cendikia Kotabumi ini. Yang juga tidak kalah pentingnya dari partisipasi tersebut diatas, adalah saran dan kritik yang membangun dari pembaca yang budiman agar kiranya dapat disampaikan langsung kepada redaksi JIK. Saran dan kritik yang membangun akan dijadikan masukan dan pertimbangan yang sangat berarti guna peningkatan mutu dan kualitas Jurnal Informatika dan Komputer STMIK Dian Cipta Cendikia Kotabumi.

Tak lupa diucapkan terima kasih yang tak terhingga atas perhatian dan kerjasama dari semua pihak yang tak dapat disebutkan satu persatu hingga dapat diterbitkan nya Jurnal Informatika dan Komputer (InfoKom) STMIK Dian Cipta Cendikia Kotabumi. Semoga apa yang telah diperbuat untuk kebaikan akan menjadi amal ibadah, amin.

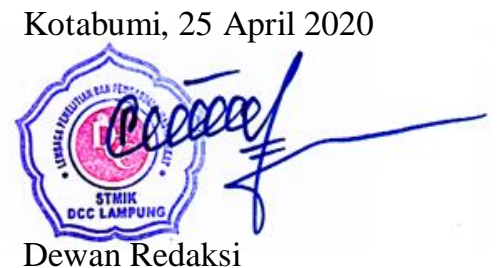




\section{JURNAL INFORMASI DAN KOMPUTER}

Volume 8 Nomor 1 April 2020

Jurnal Informasi dan Komputer merupakan Sarana informasi ilmu pengetahuan, Tekhnologi dan Komunikasi yang berupa hasil penelitian, tulisan ilmiah, Ataupun studi pustaka. Jurnal ini terbit dua kali setahun pada bulan April dan Oktober. Berisi hasil penelitian ilmiah di bidang informatika yang bertujuan untuk menghubungkan adanya kesenjangan antar kemajuan teknologi dan hasil penelitian. Jurnal ini di terbitkan pertama kali pada tahun 2013.

Penanggung Jawab:

Ketua STMIK Dian Cipta Cendikia

Kotabumi

\section{Pembina:}

Ketua STMIK Dian Cipta Cendikia

Kotabumi

Ketua Lembaga Penelitian STMIK Dian

Cipta Cendikia Kotabumi

\section{Pimpinan Redaksi}

Dwi Marisa Efendi,.S.Kom.,M.Ti

\section{Redaksi pelaksana}

Rustam,.S.Kom,.M.Ti (STMIK Dian

Cipta Cendikia Kotabumi)

Nurmayanti M.Kom (STMIK Dian

Cipta Cendikia Kotabumi)

Sukatmi,.S.Kom., M.Kom (AMIK DCC

Bandar Lampung)

Sampurna Dadi Riskiono,M.Kom

(Universitas Teknokrat Indonesia)

Ifo Wahyu

Pratama,S.Kom.,M.Ti(AMIK MASTER

Lampung)

\section{Mitra Bestari}

Merri Parida.,M.Kom (STMIK Dian

Cipta Cendikia Kotabumi)

Amarudin,S.Kom.,M.Eng (Universitas

Teknokrat Indonesia)

Didi Susianto.,S.T.,M.Kom (AMIK

DCC Bandar Lampung)

Alhibarsyah.,S.T.,M.Kom (Stmik Tunas

Bangsa Bandar Lampung)

Kemal Farouq Mauladi

.,S.Kom.,M.Kom (Universitas Islam

Lamongan)

Agus Setiawan S.Pd.,M.Eng

(Universitas Muhammadiyah

Lamongan)

Penerbit : STMIK Dian Cipta Cendikia Kotabumi Bekerja Sama Dengan LPPM STMIK Dian Cipta Cendikia Kotabumi.

\section{Alamat Redaksi/Penerbit:}

Jl. Negara No. 3 Candimas Kotabumi

Lampung Utara

No Telpon/Fax 072423003

Email :1ppm-stmik@dcc.ac.id 


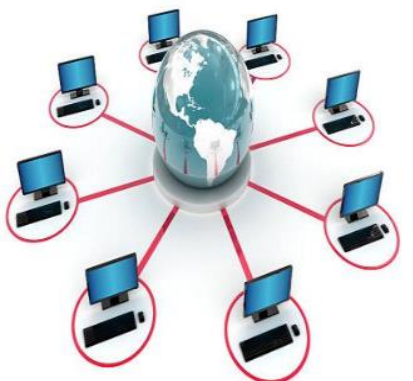 \\ JURNAL INFORMASI DAN KOMPUTER VOL. 8 NO. 1 THN. 2020}

\section{DAFTAR ISI}

\section{Halaman}

Sistem Pendukung Keputusan Penentuan Lahan Kopi Terbaik Dengan Metode

Ahp (Analytic Hierarchy Process)

Sidik Rahmatullah, Rendy Abdurahman (AMIKKOM Jogja,

STMIK Dian Cipta Cendikia Kotabumi)

Rancang Bangun Sistem Informasi Pada Program Pembangunan Pemberdayaan

Masyarakat Desa( P3md ) Berbasis Web Mobile

Ferly Ardhy, Firmansyah, Sidik Rahmatullah,(IIB Darma Jaya Bandar Lampung

STMIK Dian Cipta Cendikia Kotabumi, AMIKKOM Jogja)

Sistem Informasi Pengolahan Data Alumni Sekolah Menengah Atas (Sma)

Merri Parida, Nindiya Ova Rahmawati (AMIKKOM Jogja,

STMIK Dian Cipta Cendikia Kotabumi)

SISTEM INFORMASI GEOGRAFIS PUSKESMAS BESERTA SARANA

DAN PRASARANA BERBASIS WEB MOBILE

Nurmayanti, Windy Dwi Bahari (AMIKOM Jogja,

STMIK Dian Cipta Cendikia Kotabumi)

Rancang Bangun Sistem Informasi Konseling Untuk Sekolah Menengah Kejuruan

(Smk) Berbasis Website

Aliy Hafiz1, Galih Rakasiwi, Ifo Wahyu Pratama, Agus Komarudin,

Bambang Suparapto, Fathurrahman Kurniawan Ikhsan

(AMIK Dian Cipta Cendikia Bandar Lampung,

Universitas Nahdhatul Ulama Lampung, AMIK Dian Cipta Cendikia Pringsewu,

Universitas Mitra Indonesia, Lampung) .....

Sistem Pendukung Keputusan Pemilihan Driver Terbaik Menggunakan Metode

Weight Product (Wp)

Dina Lorenza, Pitrawati (STMIK Dian Cipta Cendikia Kotabumi

AMIK Dian Cipta Cendikia)

Rancang Bangun Sistem Informasi Pembayaran Mahasiswa

Darsin(Universitas Megou pak Tulang Bawang)

Sistem Informasi Geografis Bengkel Motor Honda Resmi Bandar Lampung

Sukatmi, Nuraini (AMIK Dian Cipta Cendikia Bandar Lampung).....

Sistem Pakar Diagnosa Penyakit Kulit Wajah Dengan Metode

Certainty Factor Pada Klinik Skin Rachel

Dwi Marisa Efendi, Putri Yulita Sari (IIB Darmajaya Bandar Lampung,

STMIK Dian Cipta Cendikia Kotabumi)..... 
Sistem Informasi Monitoring Siswa Pada Mts Al-Islamiah Bunut Kabupaten Pesawaran Yuli Syafitri ${ }^{2}$, Reni Astika ${ }^{1}$, Septian Hernando $^{3}$ AMIK Dian Cipta Cendikia

Aplikasi Kamus Bahasa Jepang Berbasis Mobile Android

Rustam $^{2}$, A Yanda Febry Pangestu ${ }^{2}$ Sistem Informasi, Teknologi Komputer ${ }^{1}$, IIB Darmajaya

Bandar Lampung ${ }^{2}$ STMIK Dian Cipta Cendikia Kotabumi 


\title{
SISTEM INFORMASI GEOGRAFIS BENGKEL MOTOR HONDA RESMI BANDAR LAMPUNG
}

\author{
Sukatmi $^{1}$, Nur Hasan ${ }^{2}$ \\ Magister Teknologi Informatika ${ }^{1,}$ Manajemen Informatika ${ }^{2}$ \\ IIB Darmajaya Bandar Lampung ${ }^{1}$ AMIK DCC Bandar Lampung ${ }^{2}$ \\ Jl. Cut Nyak Dien No. 65 Bandar Lampung, 0721- 250766, \\ Email : Sukatmi@dcc.ac.id.
}

\begin{abstract}
ABSTRAK
Bengkel motor merupakan tempat dimana motor dimodifikasi atau diperbaiki. Bengkel motor Honda resmi merupakan tempat dimana motor keluaran Honda dimodifikasi atau diperbaiki. Pemakai motor Honda sudah mendominasi masyarakat Bandar Lampung. Oleh karena itu perlu dibangun sebuah sistem yang dapat mempermudah masyarakat Bandar Lampung dalam mencari lokasi bengkel motor Honda yang resmi yang ada di Bandar Lampung.

Tujuan penelitian ini adalah untuk menghasilkan aplikasi WebGIS yang dapat digunakan untuk mencari lokasi bengkel Honda resmi secara online. Teknik pengumpulan data yang diguankan adalah studi pustaka dan observasi. Metode Pengembangan Sistem yang digunakan Extreme Programming, yang memiliki keunggulan pengembangan sistem yang lebih cepat dan proses pengembangan lebih responsive. Alat pengembangan sistem yang digunakan adalah Unified Modeling Language (UML) yang meliputi use case diagram, class diagram dan activity diagram. Adapun bahasa pemrograman yang digunakan adalah HTML dan PHP dengan database MySql.

Aplikasi WebGis dapat digunakan oleh semua orang untuk mencari bengkel Honda resmi yang ada di Bandar Lampung dengan dilengkapi fasilitas dari google maps berikut dengan informasi mengenai fasilitas yang ada di bengkel masing-masing.
\end{abstract}

Kata kunci : Sistem Informasi Geografis, Bengkel Motor Honda Resmi, Extreme Programming, Unified Modeling Language, HTML, PHP.

\begin{abstract}
Bike shop is used to repair the motor. bike shop is the official Honda motorcycle workshop. therefore, an application was made to find a Honda workshop in Lampung city.

Collection techniques used were literature study and observation. The System Development Method used is Extreme Programming. The system development tool used is the Unified Modeling Language (UML) which includes use case diagrams, class diagrams and activity diagrams. The programming languages used are HTML and PHP with MySql databases.
\end{abstract}

The WebGis application can be used by everyone. WebGis application is equipped with facilities from Google Maps along with information about the facilities in each workshop.

Keyword : Geographic Information System, Official Honda Motorcycle Repair Shop, Extreme Programming, Unified Modeling Language, HTML, PHP. 


\section{PENDAHULUAN}

Pesatnya kemajuan jaman, membuat kendaraan bermotor sangat dibutuhkan sebagai media transportasi. Kendaraan bermotor membuat efisiensi waktu dan tenaga karena diciptakan memang untuk membantu aktivitas manusia. Demi kelancaran tugas maupun pekerjaan, kendaraan pribadi seperti sepeda motor merupakan salah satu aset utama untuk mendukung kelancaran mobilitas tersebut.

Tuntutan mobilitas yang tinggi mungkin saja menemukan kendala-kendala yang dapat menghambat mobilitas tersebut. Misalnya, kondisi jalanan yang macet, mendapati ban kendaraan bocor di jalan karena tertusuk paku, maupun masalah pada kendaraan yang digunakan. Menyikapi kendala yang terakhir ini, bengkel merupakan salah satu alternatif untuk memperbaiki masalah-masalah yang mungkin saja terjadi pada kendaraan.

Pengetahuan yang terbatas terhadap kondisi lingkungan sekitar membuat informasi tentang bengkel yang tersedia ini menjadi sulit untuk didapat. Bertanya pada pengguna jalan sekitar juga tidak menjamin terkumpulnya informasi yang akurat. Teknologi yang semakin maju dan berkembangnya kehadiran suatu sistem informasi yang dapat memberitahukan letakgeografi serta informasi tentang bengkel yang tersedia di wilayah itu akan sangat membantu para pemilik kendaraan.

Berdasarkan uraian tersebut, perlu kiranya dibangun Sistem informasi Geografis (SIG) bengkel motor Honda resmi di Bandar Lampung. Dengan adanya sistem informasi geografis bengkel motor Honda resmi Bandar lampung dapat memudahkan bagi masyarakat mencari lokasi bengkel motor Honda terdekat.

\section{METODE PENELITIAN}

\subsection{Alat Perancangan}

Dalam penelitian ini, yang digunakan sebagai sarana untuk membuat rancangan sistem adalah Unified Modelling Language (UML) yang meliputi usecase diagram untuk menggambarkan model sistem, activity diagram untuk rancangan program dan class diagram untuk rancangan basis data.

\subsection{Metode Pengembangan}

Metode pengambangan sistem yang digunakan dalam penelitian ini adalah Extreme Programming (XP). Pada metode ini Paradigma pembangunan mencakup seperangkat aturan dan praktik yang terjadi dalam konteks kerangka empat kegiatan yaitu: perencanaan, desain, pengkodean, dan pengujian. Keempat aktivitas inilah yang akan menghasilkan sebuah perangkat lunak yang didasari dengan konsep model Extreme Programming. (Pressman: 2010: 73). Gambar dibawah ini selain memberikan kesimpulan bagaimana penggunaan Extreme Programming

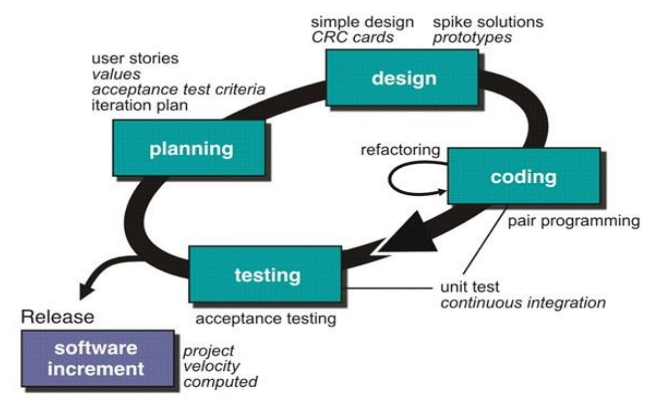

Gambar 1. Kerangka Kerja Extreme Programming

\section{A, Planning}

Pada tahap ini peneliti melakukan identifikasi kebutuhan sehingga diketahui kebutuhan input dan kebutuhan output. Kebutuhan input meliputi data lokasi, data benkel dan informasi terkait dengan bengkel. Kebutuhan output meliputi peta lokasi bengkel dan informasi yang terkait dengan bengkel yang bersangkutan.

\section{B. Design}

\section{B.1 Model Sistem}

Model sistem untuk pengembangan sistem informasi geografis bengkel motor Honda resmi Bandar Lampung digambarkan dalam bentuk usecase diagram sebagai berikut.

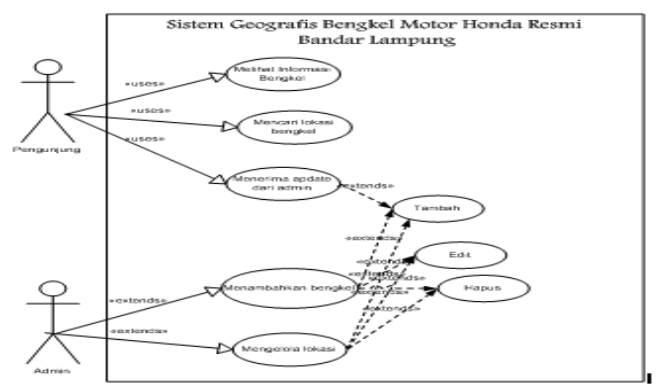


Gambar 2. Model Sistem SIG Bengkel Motor Honda Bandar Lampung

\section{B.2 Rancangan Basis Data}

Rancangan basis data untuk pengembangan sistem informasi geografis bengkel motor Honda resmi Bandar Lampung dibuat dalam bentuk class diagram sebagai berikut.

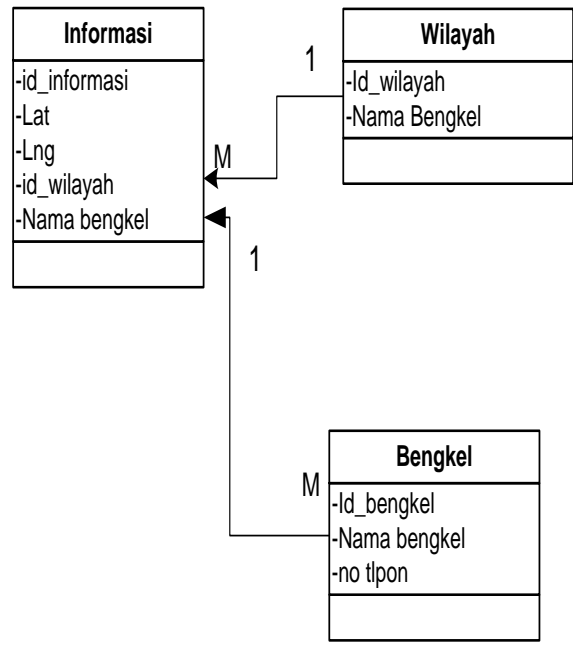

Gambar 3. Rancangan Basis Data

\section{B.3 Rancangan Input dan Output}

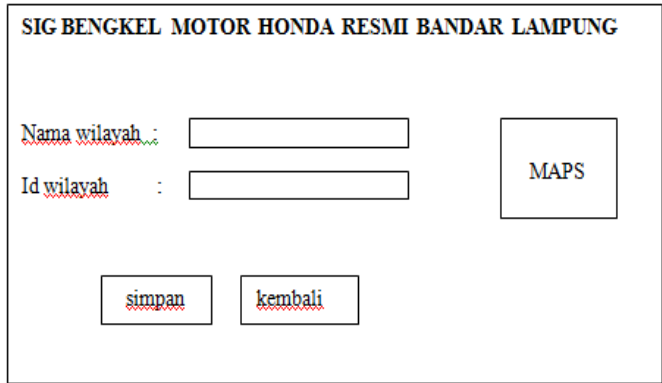

Gambar 4. Rancangan Input Wilavah

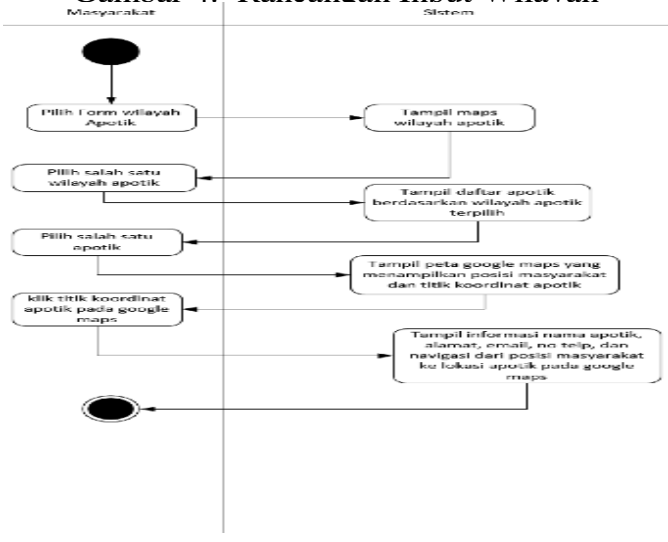

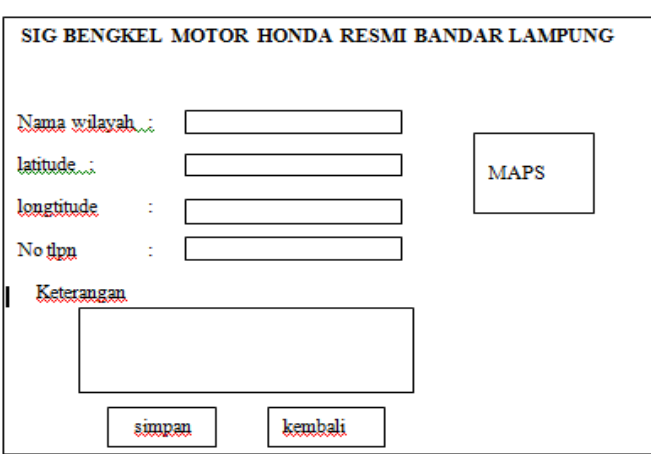

Gambar 6. Rancangan Input Informasi tentang Bengkel

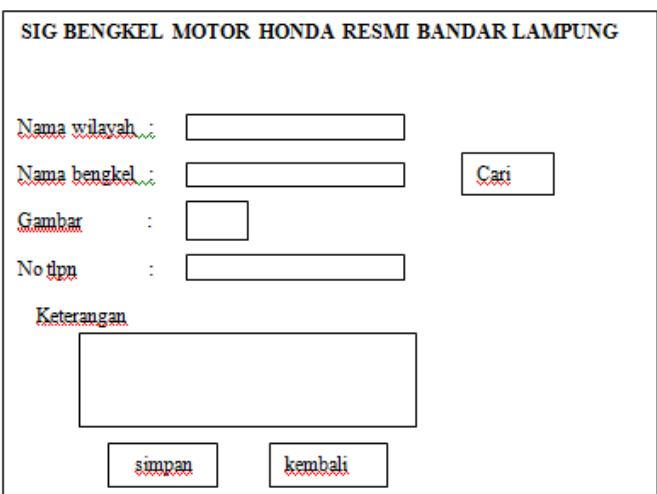

Gambar 7. Rancangan Output SIG Bengkel Motor Honda Bandar Lampung

\section{B.4 Algoritma Program}

Algoritma program untuk pengembangan sistem informasi geografis bengkel motor Honda resmi Bandar Lampung dibuat dalam activity diagram sebagai berikut.

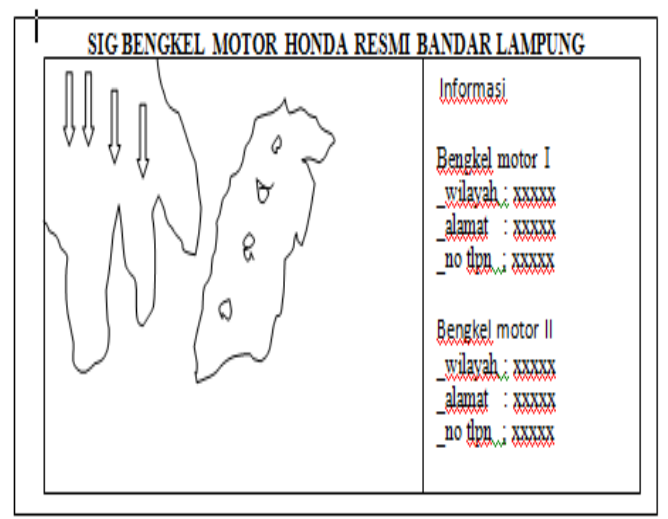

Gambar 8. Activity Diagram Pengolahan Data Lokasi 


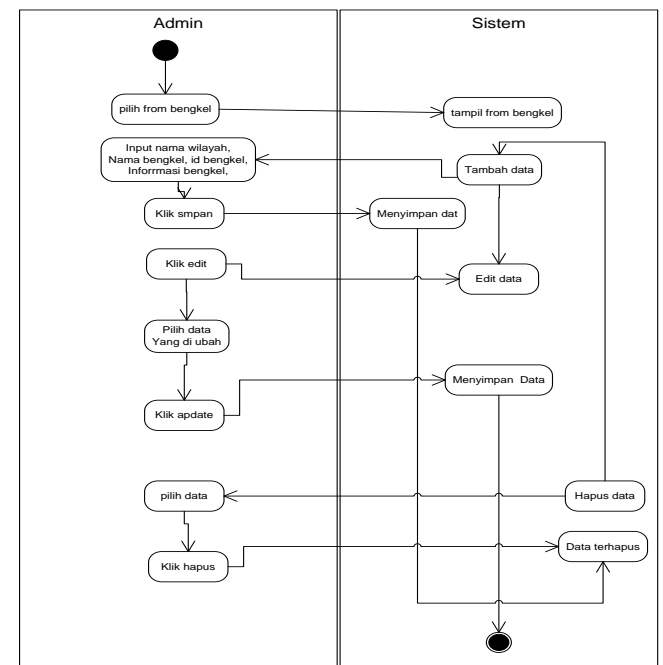

Gambar 9. Activity Diagram Pengolahan Data Bengkel

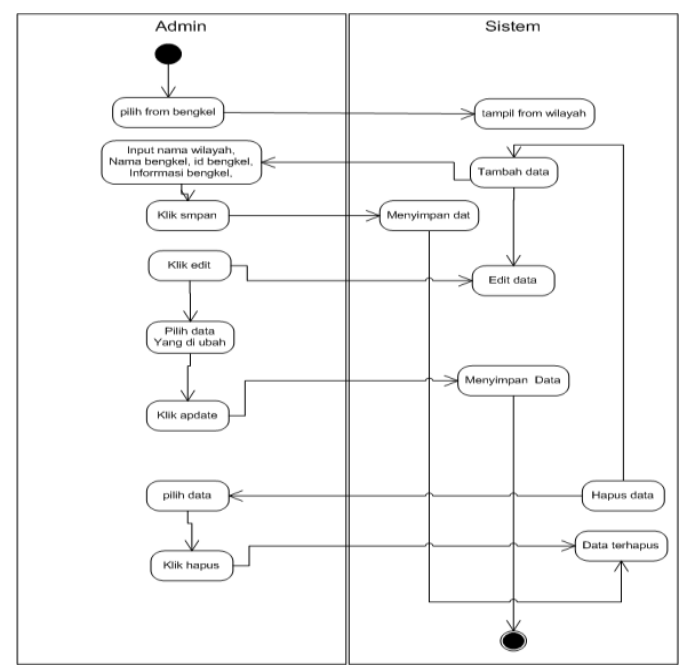

Gambar 10. Activity Diagram Akses Masyarakat Pengguna

\section{HASIL DAN PEMBAHASAN}

\subsection{Login Admin}

Halaman ini merupakan halaman untuk masuknya admin kedalam halaman Administrator dimana setiap berita atau informasi yang ingin di upload harus melalui halaman tersebut.

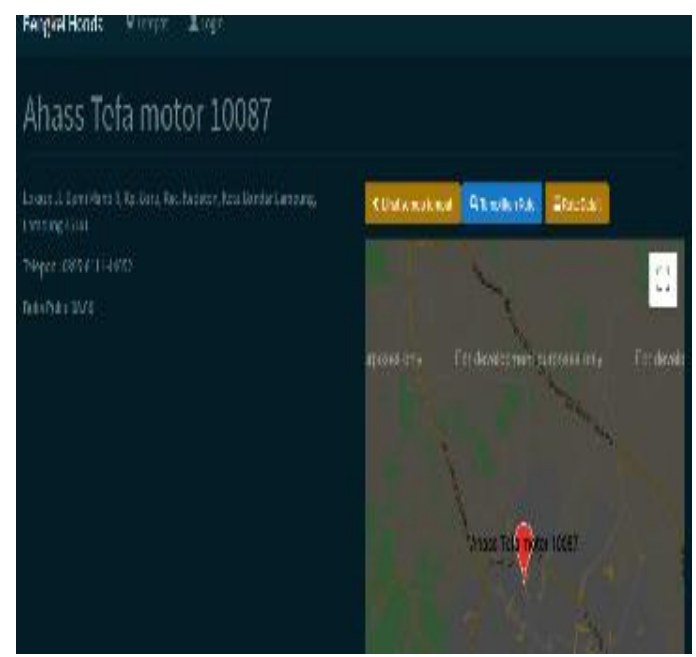

Gambar 11. Login Halaman Admin

\subsection{Output WebGIS Bengkel Motor Honda Resmi Bandar Lampung}

Halaman ini merupakan tampilan pertama saat user menjalankan aplikasi ini. Selanjutnya melalui halaman beranda berikut user dapat mencari lokasi bengkel motor Honda resmi terdekat. Selanjutnya akan diperoleh hasil lokasi bengkel terdekat dalam bentuk peta/map. Dari halaman tersebut user juga dapat mendapatkan informasi yang terkait dengan bengkel tersebut.

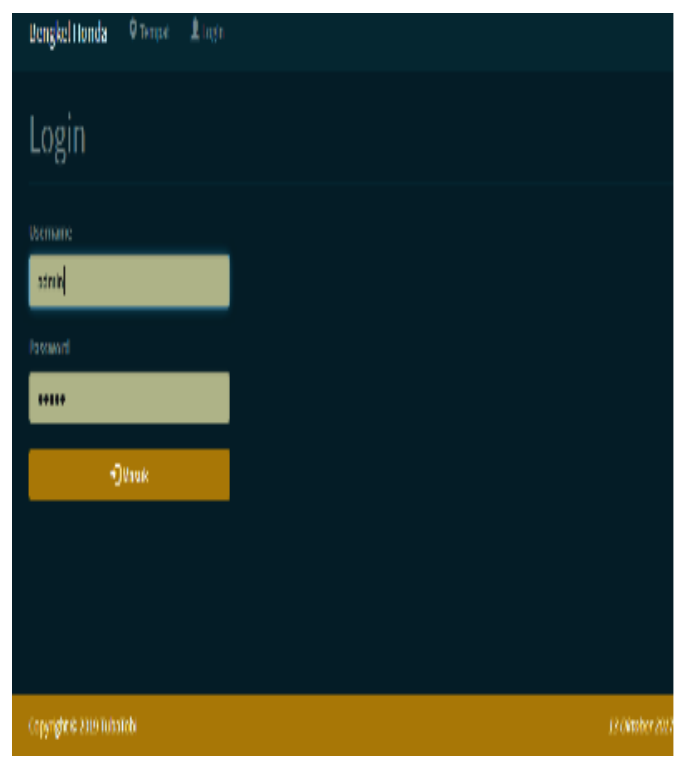

Gambar 12. Halaman Utama 


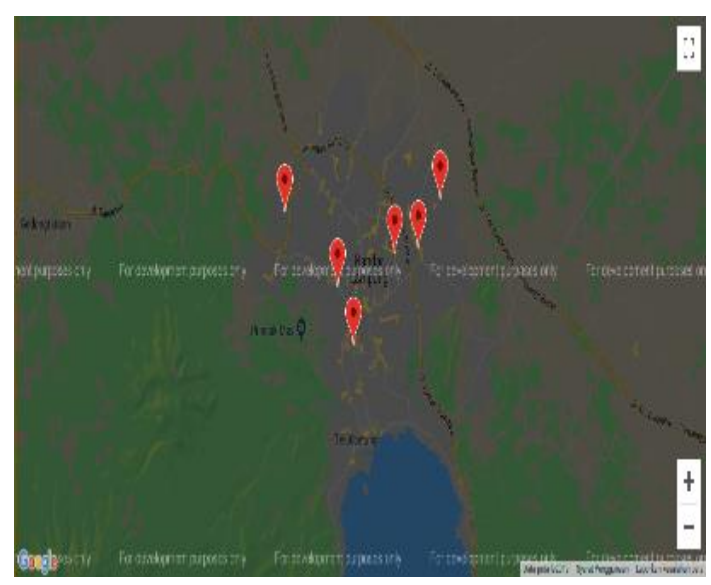

Gambar 13. Output Lokasi dan Informasi Bengkel

\section{PENUTUP}

Dari hasil penelitian dapat dsimpulkan bahwa sistem informasi geografis bengkel motor Honda resmi Bandar Lampung sangat dibutuhkan masyarakat guna membantu mencari lokasi dan informasi bengkel Honda yang dibutuhkan. Aplikasi yang dikembangkan dalam penelitian ini menghasilkan Sistem Informasi Geografis Bengkel Motor Honda Resmi di Bandar Lampung yang dapat diakses masyarakat guna membantu mencari lokasi dan informasi bengkel Honda resmi yang dibutuhkan.

\section{DAFTAR PUSTAKA}

[1] Mustofa, Wahyu Dwi, 2015, Perancangan Aplikasi Pencarian Bengkel di Kabupaten Gunung Kidul Menggunakan Global Positioning System(GPS) Berbasis Android. STMIK AMIKOM, Yogyakarta

[2] Priyani Tutty, 2014, Rancang Bangun Sistem Informasi Geografis Lokasi Balai Kesehatan yang Bekerjasama Dengan BPJS Dengan Menggunakan Metode Waterfall, Universitas Bandar Lampung

[3] Sugiarti, Yuni, 2013, Analisis dan Perancangan Unified Modelling Language), Graha Imu, Yogyakarta.
[4] Tjiptanata Agus, Ricky, 2011, Sistem Informasi Geografis Rumah Sakit Berbasis Web. Seminar Nasional dan Ekspo, Teknik Elektro, Depok, Indonesia, ISSN : 2088-9984

[5] Wahana Komputer, 2011, Adobe Dreamweaver CS5 Untuk Beragam Desain Website Interaktif, Yogyakarta, Andi

[6] Wahana Komputer, 2009, Java Programming, Yogyakarta, Andi Offset

[7] Yuliani, Sylvia Tri. (2016). Aplikasi Sistem Informasi Geografis (SIG) Untuk Pemetaan Pasar Tradisional Di Kota Semarang Berbasis Web. Jurnal Geodesi UNDIP. ISSN : 2337-845X. Volume 5, Nomor

[8] Efendi, Dwi Marisa, Muhammad Bayu, and Joni Darsyah. "Sistem Informasi Geografis Lokasi Kos Dan Penginapan Berbasis Web Pada Wilayah Kotabumi Kabupaten Lampung Utara." Jurnal Informasi Dan Komputer 6.2 (2018): 1-10. 